\title{
Role of interferon gamma in SARS-CoV-2-positive patients with parasitic infections
}

Enas Fakhry Abdel-Hamed ${ }^{1 *} \mathbb{D}$, Mohamed N. Ibrahim², Nahed E. Mostafa ${ }^{1}$, Howayda S. F. Moawad', Nahla E. Elgammal ${ }^{3}$, Ehab M. Darwiesh ${ }^{3}$, Dina S. El-rafey ${ }^{4}$, Nissreen E. ElBadawy ${ }^{5}$, Emad Ali Al-Khoufi ${ }^{6}$ and Salwa I. Hindawi ${ }^{7}$

\begin{abstract}
Background: By 27 June 2020, almost half a million people had died due to COVID-19 infections. The susceptibility and severity of infection vary significantly across nations. The contribution of chronic viral and parasitic infections to immune homeostasis remains a concern. By investigating the role of interferon (IFN)- $\gamma$, we conducted this study to understand the connection between the decrease in numbers and severity of COVID-19 cases within parasitic endemic regions. Our research included 375 patients referred to hospitals for diagnosis of COVID-19 infection. Patients were subjected to full investigations, in particular severe acute respiratory syndrome coronavirus-2 nucleic acid and Toxoplasma IgM and lgG antibody detection, stool examination, and quantitative IFN- $\gamma$ measurement.

Results: The majority of the studied cases had chest manifestation either alone (54.7\%) or in association with gastrointestinal (GIT) manifestations (19.7\%), whereas $25.6 \%$ had GIT symptoms. We reported parasitic infections in $72.8 \%$ of mild COVID-19 cases and 20.7\% of severe cases. Toxoplasma gondii, Cryptosporidium, Blastocyst, and Giardia were the most common parasitic infections among the COVID-19 cases studied.

Conclusion: The remarkable adaptation of human immune response to COVID-19 infection by parasitic infections with high levels of IFN- $\gamma$ was observed in moderate cases compared with low levels in extreme cases. The potential therapeutic efforts aimed at the role of parasitic infection in immune system modulation are needed if this hypothesis is confirmed.
\end{abstract}

\section{Introduction}

Severe acute respiratory syndrome coronavirus-2 (SARS$\mathrm{CoV}-2)$ is an intercontinental pandemic triggered by the universal human-to-human transmission of the virus [1]. Meaningful variations are observed in the way COVID19 spreads across different regions on various continents [2].

\footnotetext{
*Correspondence: enas_refae1983@yahoo.com

${ }^{1}$ Medical Parasitology Department, Faculty of Medicine, Zagazig University, El Kawmia Square, Zagazig 44511, Sharkia Governorate, Egypt

Full list of author information is available at the end of the article
}

Malaria-endemic countries have reported a low number of COVID-19 cases [3]. The populations in these areas have natural protection against malaria infection by producing a combination of Th1 and Th 2 responses. In several coinfections, malaria-induced immunosuppression also severely inhibits immune responses to other infections, such as Salmonella spp. [4]. By inhibiting the activity of CD8+ T-cell migration, Plasmodium infection protects against the Chikungunya virus [5].

Toxoplasma gondii is an intracellular parasite that generates dense granuleprotein-7 (GRA-7) into the host cell, which inhibits viral replication [6]. Based on the antagonistic phenomenon in which certain pathogens can 
inhibit another infection by limiting its invasion, survival, and reproduction, various parasites have weakened the severity of viral infections [7]. In addition, the concurrent infection of Giardia and Rotavirus reduces the severity of the related viral infection [8].

The most frequent symptoms of patients infected with SARS-CoV-2 upon admission are history of fever, shortness of breath, cough, fatigue/malaise, and confusion, according to the Center for Disease Control and Prevention [9]. The pathogenesis of human infection with SARS-CoV-2 manifests as mild symptoms to extreme respiratory failure. The virus replicates and migrates across the airways upon binding to epithelial cells of the respiratory tract. The rapid replication of SARS-CoV-2 in the lungs elicits an effective immune response. After the relief of clinical symptoms and negative reversetranscriptase polymerase chain reaction (RT-PCR) assay findings, this viral infection displays an inflammatory response resulting in lung fibrosis [10].

Cytokine storm syndrome, which is considered the primary cause of death in patients, induces acute respiratory distress syndrome and respiratory failure. The serum of hospitalized patients with severe COVID-19 contain elevated levels of tumor necrosis factor, interleukin (IL)-2, IL-10, IL-7, granulocyte colony-stimulating factor, C-X-C motif chemokine ligand 10 , and macrophage inflammatory protein $1 \alpha$ [11]. Interferons (IFNs) are well-known cytokines for their antiviral effects; they play a critical role in viral multiplication drop off [12]. The expression of IFN- $\gamma$ receptors is limited to epithelial cell-enriched tissues, such as the lungs, skin, gastrointestinal tract (GIT), and respiratory tract. This receptor allocation pattern renders IFN- $\gamma$ with the capability to target specific tissues [13]. The IFN- $\gamma$ levels are negatively related to the increase in the amount of COVID-19 fibrosis at discharge. These results indicate the early interference of IFN- $\gamma$ antiviral infection and inhibition of fibrosis for improved recovery [14].

We conducted this study to realize the relationship between the decrease in numbers and severity of COVID-19 cases within parasitic endemic areas by investigating the role of IFN- $\gamma$.

\section{Results}

This research included 375 patients diagnosed with COVID-19 positive $(+$ ve) via PCR tests. The patients were aged18-69 years old, with a mean age of 44.72 years, and of which $65.6 \%$ were male, and $34.4 \%$ were female. Employers (24.8\%) and specialists (18.4\%) were the most frequent occupations among the studied population, as shown in Table 1 . In terms of comorbidity, $40 \%$ of patients had other systemic disorders, with chronic lung disease (19.7\%) being the most common.
Table 1 Characters of SARS-CoV-2 + ve patients

\begin{tabular}{|c|c|c|}
\hline \multirow[t]{2}{*}{ Characteristics } & \multicolumn{2}{|l|}{$(n=375)$} \\
\hline & $\mathbf{N}$ & $\%$ \\
\hline \multicolumn{3}{|l|}{ Sex } \\
\hline Male & 246 & 65.6 \\
\hline Female & 129 & 34.4 \\
\hline \multicolumn{3}{|l|}{ Age } \\
\hline Mean $\pm S D$ & $44.72 \pm 13.82$ & \\
\hline Range & $18-69$ & \\
\hline \multicolumn{3}{|l|}{ Occupation } \\
\hline Student & 29 & 7.7 \\
\hline Unemployed house wife & 51 & 13.6 \\
\hline Retired & 24 & 6.4 \\
\hline Farmer & 12 & 3.2 \\
\hline Skilled or worker & 65 & 17.3 \\
\hline Employer & 93 & 24.8 \\
\hline Specialist & 69 & 18.4 \\
\hline Health care worker & 32 & 8.5 \\
\hline \multicolumn{3}{|l|}{ Chronic comorbidities } \\
\hline No & 225 & 60 \\
\hline Yes & 150 & 40 \\
\hline Hypertension & 12 & 3.2 \\
\hline Diabetes mellitus & 12 & 3.3 \\
\hline Hypertension + diabetes mellitus & 8 & 2.1 \\
\hline Chronic heart disease & 21 & 5.6 \\
\hline Chronic lung disease & 74 & 19.7 \\
\hline Chronic heart + chronic lung diseases & 10 & 2.7 \\
\hline Immunosuppression & 13 & 3.5 \\
\hline \multicolumn{3}{|l|}{ COVID-19 symptoms } \\
\hline GIT manifestation & 96 & 25.6 \\
\hline Chest and GIT manifestations & 74 & 19.7 \\
\hline \multicolumn{3}{|l|}{ Covid-19 severity } \\
\hline Mild & 346 & 92.3 \\
\hline Severe (admission ICU) & 29 & 7.7 \\
\hline
\end{tabular}

The majority of cases examined had chest manifestations either alone (54.7\%) or in association with GIT manifestations $(19.7 \%)$, whereas only GIT symptoms were present in $25.6 \%$. In $92.3 \%$ of the studied cases, the severity of COVID-19 was mild, and a severe condition was noted in $7.7 \%$ (required intensive care unit (ICU) admission) (Table 1).

The prevalence of parasitic infections among the studied COVID-19 cases was $68.8 \%$. The most commonly found parasites were Toxoplasma gondii (22.4\%), Cryptosporidium (19.7\%), Blastocyst (17.6\%), Giardia (9.1\%), and Cryptosporidium + Blastocyst + Entamoeba histolytica combined infection (6.1\%) (Fig. 1).

Table 2 reveals the relationship between the severity of COVID-19 infection and symptoms, where all confirmed 


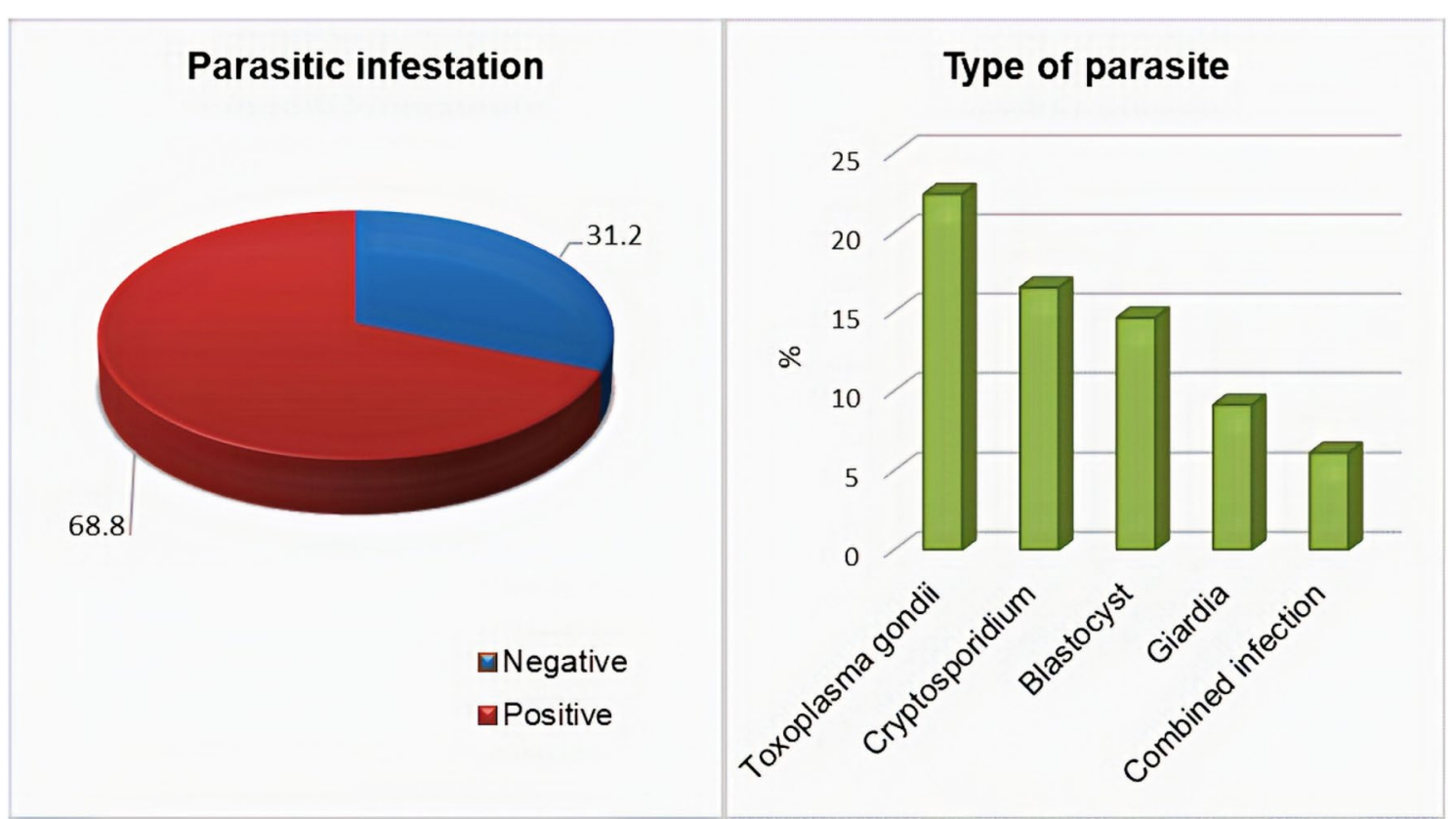

Fig. 1 Frequency of parasitic infections and types of parasite among SARS-CoV-2 + ve patients

Table 2 Relation between severity of SARS-CoV-2 and manifestation

\begin{tabular}{|c|c|c|c|c|c|c|}
\hline \multirow[t]{2}{*}{ Manifestation } & \multicolumn{2}{|c|}{ Mild $(n=346)$} & \multicolumn{2}{|c|}{ Severe $(n=29)$} & \multirow[t]{2}{*}{$x^{2}$} & \multirow[t]{2}{*}{$P$} \\
\hline & $\mathrm{N}$ & $\%$ & $\mathrm{~N}$ & $\%$ & & \\
\hline Chest manifestation & 176 & 50.9 & 29 & 100 & 26.06 & $<0.001^{* *}$ \\
\hline GIT manifestation & 96 & 27.7 & 0 & 0 & & \\
\hline Chest \& GIT manifestations & 74 & 21.4 & 0 & 0 & & \\
\hline
\end{tabular}

$X^{2}$ Chi-square test, ${ }^{* *}$ highly significant $(P<0.01)$

severe cases showed chest symptoms only with a highly statistically significant difference $(P<0.001)$ compared with the mild cases. The mild cases showed chest symptoms (50.9\%), GIT symptoms (27.7\%), and mixed chest and GIT symptoms $(21.4 \%)$ with a highly statistically significant difference $(P<0.001)$. Reviewing the relation between parasitic infected cases and the severity of this viral infection, $72.8 \%$ and $20.7 \%$ of mild and severe cases had parasitic infection, respectively (Table 3 ). Additionally, $91.7 \%$ of cases with diabetes mellitus had parasitic infections, and $75 \%$ of hypertensive cases and $100 \%$ of immune-compromised patients had parasitic infections with a statistically significant difference $(P<0.05)$. A highly statistically significant increase was observed in the frequency of infections among cases with GIT symptoms (78.1\%) and combined GIT and chest symptoms (83.8\%) compared with cases with chest symptoms only (59\%), indicating a high statistically significant difference $(P<0.001)$.
The parasitic infection modulated the human immune response to COVID-19 infection in mild cases with high levels of IFN (50.17 \pm 8.24$)$ compared with those with low levels of IFN (9.17 \pm 1.60$)$ in severe cases (Table 4).

\section{Discussion}

Our results reported the decreased incidence and severity of SARS-CoV-2 disease in patients with parasitic infections compared with those who had SARS-CoV-2 alone. Among the examined COVID-19 cases, the prevalence of parasitic infections was $68.8 \%$ with a highly statistically significant increase $(P<0.001)$ in mild cases (72.8\%) compared with that in severe cases $(20.7 \%)$. The most commonly identified parasites (Fig. 1) were Toxoplasma gondii (22.4\%), Cryptosporidium (19.7\%), Blastocyst (17.6\%), and Giardia (9.1\%).

In our research, the path of the disease was mild given that spontaneous resolution occurred in Toxoplasma gondii-infected patients. These results can be explained 
Table 3 Comparison between parasitic infected cases and free cases in terms of demographic data, comorbidity, SARS-CoV-2 manifestation, and severity

\begin{tabular}{|c|c|c|c|c|c|c|c|c|}
\hline \multirow{2}{*}{$\begin{array}{l}\text { Characteristics } \\
\text { Age }\end{array}$} & \multirow[t]{2}{*}{ Total } & \multicolumn{3}{|c|}{ Negative $(-v e)(n=117)$} & \multicolumn{2}{|c|}{ Positive $(+v e)(n=258)$} & \multirow[t]{2}{*}{$\mathrm{t}$} & \multirow[t]{2}{*}{$P$} \\
\hline & & & & & & & & \\
\hline Mean \pm SD & \multirow[t]{2}{*}{375} & \multicolumn{2}{|c|}{$43.37 \pm 10.62$} & \multicolumn{3}{|c|}{$45.11 \pm 12.53$} & 1.30 & 0.19 \\
\hline Range & & \multicolumn{2}{|c|}{$18-67$} & \multicolumn{3}{|c|}{$19-69$} & & NS \\
\hline Characteristics & & Total & $\mathbf{N}$ & $\%$ & $\mathrm{~N}$ & $\%$ & $x^{2}$ & $P$ \\
\hline \multicolumn{9}{|l|}{ Sex } \\
\hline Male & & 246 & 75 & 30.5 & 171 & 69.5 & 0.17 & 0.68 \\
\hline Female & & 129 & 42 & 32.6 & 87 & 67.3 & & NS \\
\hline \multicolumn{9}{|l|}{ Occupation } \\
\hline Student & & 29 & 11 & 37.9 & 18 & 62.1 & & \\
\hline Unemployed-housewife & & 51 & 13 & 25.5 & 38 & 74.5 & & \\
\hline Retired & & 24 & 10 & 41.7 & 14 & 58.3 & & \\
\hline Farmer & & 12 & 1 & 8.3 & 11 & 91.7 & & \\
\hline Skilled or worker & & 65 & 23 & 35.4 & 42 & 64.6 & 14.98 & $0.04^{*}$ \\
\hline Employer & & 93 & 35 & 37.6 & 58 & 62.4 & & \\
\hline Specialist & & 69 & 21 & 30.4 & 48 & 69.6 & & \\
\hline Health care worker & & 32 & 3 & 9.4 & 29 & 90.6 & & \\
\hline \multicolumn{9}{|l|}{ Chronic comorbidities } \\
\hline No & & 225 & 69 & 30.7 & 156 & 69.3 & 0.07 & 0.78 \\
\hline Yes & & 150 & 48 & 32 & 102 & 68 & 0.07 & NS \\
\hline Hypertension & & 12 & 5 & 41.7 & 7 & 58.3 & & \\
\hline Diabetes mellitus & & 12 & 1 & 8.3 & 11 & 91.7 & & \\
\hline $\mathrm{HPT}+\mathrm{DM}$ & & 8 & 2 & 25 & 6 & 75 & 12.58 & $0.04^{*}$ \\
\hline Chronic heart disease & & 21 & 9 & 42.9 & 12 & 57.1 & & \\
\hline Chronic lung disease & & 74 & 26 & 35.1 & 48 & 64.9 & & \\
\hline Chronic heart \& lung diseases & & 10 & 5 & 50 & 5 & 50 & & \\
\hline Immunosuppression & & 13 & 0 & 0 & 13 & 100 & & \\
\hline \multicolumn{9}{|l|}{ COVID-19 symptoms } \\
\hline Chest manifestation & & 205 & 84 & 41 & 121 & 59 & & \\
\hline GIT manifestation & & 96 & 21 & 21.9 & 75 & 78.1 & 20.67 & $<0.001^{* *}$ \\
\hline Chest \& GIT manifestations & & 74 & 12 & 16.2 & 62 & 83.8 & & \\
\hline Mild & & 346 & 94 & 27.2 & 252 & 72.8 & 33.89 & $<0.001^{* *}$ \\
\hline \multicolumn{9}{|l|}{ Covid- 19 severity } \\
\hline Severe (admission ICU) & & 29 & 23 & 79.3 & 6 & 20.7 & & \\
\hline
\end{tabular}

$S D$ standard deviation, $t$ independent $\mathrm{t}$ test, $\chi 2$ chi-square test, $N S$ non-significant, $N S$ non-significant $(P>0.05) *$ significant $(P<0.05){ }^{* *}$ highly significant $(P<0.01)$

Table 4 Relation between IFN- $\gamma$ and the severity of SARS-COV-2 with and without parasitic infection

\begin{tabular}{|c|c|c|c|c|c|c|c|}
\hline \multirow[t]{2}{*}{ IFN- $\gamma$ level $(\mathrm{pg} / \mathrm{ml})$} & \multirow[t]{2}{*}{ Total (375) } & \multicolumn{2}{|c|}{ Mild cases $(n=346)$} & \multicolumn{2}{|c|}{ Sever cases $(n=29)$} & & $P$ \\
\hline & & $\begin{array}{l}\text { With parasites } \\
(n=252)\end{array}$ & No parasites $(n=94)$ & $\begin{array}{l}\text { With parasites } \\
(n=23)\end{array}$ & No parasites $(n=6)$ & & \\
\hline Mean \pm SD & $40.29 \pm 16.94$ & $50.17 \pm 8.24 a$ & $25.49 \pm 5.92 b$ & $9.17 \pm 1.60 \mathrm{~d}$ & $0.74 \pm 0.22 c$ & 529 & $<.00$ \\
\hline
\end{tabular}

SD standard deviation, $F$ ANOVA test, ${ }^{* *}$ highly significant $(P<0.01)$

Groups with different letters are statistically significant $(P<0.05)$

by the production of GRA-7, which displays immune stimulation and a broad spectrum of antiviral activities via type I IFNs signaling [6]. Another clarification was obtained by Degrandi et al. [15], who announced that Toxoplasma-infected mice exhibited up-regulated immune responsive gene 1 in their lungs. This gene is 
an IFN-stimulated gene that mediates antiviral effects against RNA viruses [16]. Moreover, the apicoplast proteins of protozoa have immunogenic potential [17]. Priming with viable $C$. parvum oocysts provides a protective immunity at an extremely low dose. This condition restores the Th1-partner mucosal (CD8+T-cells) and their cytokine IFN- $\gamma$ effectors that otherwise decrease with ongoing protein malnutrition [18]. Nevertheless, after respiratory syncytial virus, Heligmosomoide spolygyrus considerably reduces pulmonary complications [19].

In our study, we obtained high levels of IFN- $\gamma$ $(50.13 \mathrm{pg} / \mathrm{ml})$ in mild cases compared with the low levels $(0.7385 \mathrm{pg} / \mathrm{ml})$ in severe cases of COVID-19 with parasitic infections. Chen et al. [10], who reported that IFN- $\gamma$ was lower in severe COVID-19 patients compared with those with a moderate form of the disease, approved our findings. Bajwa et al. [20] also noted the antiviral activity of IFN- $\gamma$ by exerting cellular effects at various levels. IFN- $\gamma$ interacts with the viral receptor, resulting in the consequent reduction of several virus replication downregulating genes and gene products [21]. Li and De Clercq [22] showed that IFNs are potential drug choices for SARS-CoV-2 infection.

Our main finding supports the protective role of parasitic infections against infection with COVID19. Compared with parasite-free patients, the general improvement in the overall health status of COVID-19 +ve patients was demonstrated by a rapid exit without any respiratory complications. Our findings are endorsed by Cohen et al.[23], who stated that CD4+ and CD8+ T-cells play imperative synergistic roles given that both secrete IFN- $\gamma$ during T. gondii infection. The IFN- $\gamma$ produced by $\mathrm{CD} 4+$ cells is required to prime macrophages, inducing powerful antimicrobial responses. IFN- $\gamma$ regulates the expression of inducible nitric oxide synthase, which is eventually required for parasite control [24]. Additionally, treatment with soluble T. gondii antigen $24 \mathrm{~h}$ post-P.berghei infection resulted in a rapid increase in serum IL-12 and IFN- $\gamma$ levels [25]. The development of immunity in Cryptosporidium-infected humans and murines is associated with the elevated expression of IFN- $\gamma$ Th1 cytokines [26]. In addition, the immunomodulation caused by malaria is effective against extreme manifestations of certain respiratory viruses. Hospitalized children diagnosed with influenza and malaria in Kenya are less likely to suffer respiratory distress than those with influenza alone [27].

\section{Conclusion}

Among the parasite-infected cases, the COVID-19 disease sequence was moderate. Cryptosporidium, T. gondii, Blastocyst, and Giardia were parasitic infections among the studied COVID-19 infected cases. A high percentage of moderate COVID cases accompanied with parasitic infections was observed in our results, and an increased number of serious cases were parasite free. The +ve role of parasitic infections in modulating the human immune response to COVID-19 infection was evident in the high level of IFN $\gamma$ in mild cases. A new prospect for the development of novel successful protection against COVID-19 infection has been provided by the unclear link between parasitic and viral infections. Testing the safety and efficacy of parasite-derived antigens in more patients with SARS-CoV-2 infection may be worthwhile. Our future research will focus on the cytokine storm concerning parasitic infections triggering the immunocompromised population.

\section{Material and methods Population study}

This cross-sectional analysis was conducted on 375 patients who were referred to Zagazig University Hospital and Al-Ahrar Hospital in Sharkia Province, Egypt for diagnosis of COVID-19 infection between 15 July and 10 October 2020. The requirements for diagnosis of the suspected cases of infection were sent to the Egyptian Ministry of Health Protocol for Diagnosing and Treating Cases of COVID-19. The reported patient had a strong history of epidemic exposure and had at least two of the following clinical manifestations: fever, respiratory symptoms, viral pneumonia imaging, and normal or decreased number of white blood cells and lymphocytes at the early stage of the disease. Complete blood count, SARS$\mathrm{CoV}-2$ nucleic acid detection, lung computed tomography analysis, specific Toxoplasma IgM and IgG antibody detection, and stool examination were conducted onall patients involved. No exclusion criteria were applied for the patients. The cases examined were subjected to medical history and clinical examination and then divided into those with mild disease with fever, fatigue, dry cough, and ground-glass opacities of pneumonia. The total number of white blood cells in the early stage of disease was normal or decreased, the lymphocyte count decreased, and severe disease occurred with respiratory distress (respiration rate $\geq 30$ times $/ \mathrm{min}$ ), oxygen saturation ( $\leq 93 \%$ in the resting state), $\mathrm{PaO}_{2} / \mathrm{FiO}_{2} \leq 300 \mathrm{~mm} \mathrm{Hg}$. Upon admission, blood samples were obtained from the patients. Nine days after symptoms appeared, the medication regimen was started. Mild cases appeared after a week. On the other hand, in severe cases, oral intubation was conducted in ICU during treatment.

\section{Diagnosis of COVID-19 infection}

SARS-CoV-2 RNA was investigated by RT-PCR of the combined nasopharyngeal and oropharyngeal swab 
samples of the reported cases of mild and serious infection, as per the Egyptian Ministry of Health diagnostic guideline.

Viral RNA was extracted by using the automated extraction system GenoXtract ${ }^{\circledR}$ from HAIN Lifescience GmbH (Brucker) using GXT DNA/RNA Extraction kit (CE IVD) (Primerdesign Ltd, School Lane, Chandler's Ford, UK, SO53 4DG). RT-PCR was performed with genesig ${ }^{\circledR}$ Real-Time PCR Coronavirus (COVID-19) (CE) Z-Path-COVID-19-CE- (Primerdesign Ltd, School Lane, Chandler's Ford, UK, SO53 4DG) using primers and probes targeting the RNA-dependent RNA polymerase gene fragment in Roche ${ }^{\circledR}$ LightCycler 480 II. Each $12 \mu \mathrm{L}$ reaction mixture contained $10 \mu \mathrm{L}$ oasig qPCR OneStep Master Mix and $2 \mu \mathrm{L}$ Coronavirus (COVID-19) CE IVD Primer/Probe. The thermal cycling conditionswere 10 min at $55{ }^{\circ} \mathrm{C}$ for RT, 2 min at $95{ }^{\circ} \mathrm{C}$ for initial PCR activation, and 45 cycles of 10 sat $95^{\circ} \mathrm{C}$ and 60 sat $60^{\circ} \mathrm{C}$, in accordance with the manufacturer's instructions (Primerdesign Ltd, School Lane, Chandler's Ford, UK, SO53 4DG). The+ve control template contained standardized concentrations of SARS-CoV-2 RNA (COVID-19) specific sequence at a concentration of $1.67 \times 10^{5}$ copies per $\mu \mathrm{l}$. The template should produce $\mathrm{Cq} \leq 22$ in the FAM channel to ensure the PCR run validity. Each run should contain the + ve and the negative control to produce a valid result. Analytical and clinical performances of the kit were determined by the manufacturer's instructions.

\section{Parasitological assessment Diagnosis of toxoplasmosis}

Venous blood (approximately $5 \mathrm{ml}$ ) was collected from each patient. The blood samples were labeled and refrigerated by shipment to the laboratory at $4{ }^{\circ} \mathrm{C}$. The blood samples were then centrifuged in $1.5 \mathrm{ml}$ centrifuge tubes to obtain the serum. The samples were held at $-80{ }^{\circ} \mathrm{C}$ before use. The electrochemiluminescence immunoassay (Cobas E411 immunoassay analyzers, Mannheim, Germany) was used to detect anti-Toxoplasma IgG and IgM antibodies. Master curve minimum and maximum limits specified by $0.13-650 \mathrm{IU} / \mathrm{ml}$ were detected for reference measurement.

\section{Stool examination}

Fresh stool samples from patients with manifestations of COVID-19 were collected. Direct smear, formol-ether concentration technique [28], and modified ZiehlNeelsen stain [29] were performed. On the basis of GIT manifestation of most patients, parasitological evaluation was requested.

\section{IFN- $\gamma$ measurement}

The human IFN $\gamma$ enzyme-linked immunosorbent assay kit (NOVA, No. 18, Keyuan Road, DaXing Industry Region, Beijing, China) was used to quantitatively calculate IFN- $\gamma$ in the serum of the studied population, following the manufacturer's instructions. Optical density was estimated at $450 \mathrm{~nm}$, the standard curve was built, and the mean absorbance concentration of the samples from the standard curve was measured.

\section{Statistical analysis}

The data were computerized and statistically analyzed using Statistical Package for the Social Sciences, version 25.0. Qualitative data were expressed as the number and percentage, and quantitative data were expressed as the mean, standard deviation, and range. Chi-square $\left(x^{2}\right)$ and independent $t$-tests were used in comparing data. The $\mathrm{p}$-value was considered significant if $<0.05$ and highly significant if $<0.01$.

\section{Authors' contributions}

EFAH came up with the idea, drafted the initial proposal, and finalized the manuscript. The other authors processed the data collection tools and practice data collection and analysis. All authors read and approved the manuscript.

\section{Declarations}

\section{Ethical approval and consent to participate}

The research was authorized by the Ethics Committee of the Faculty of Medicine of Zagazig University, Egypt. The + ve cases for parasites were treated. The confidentiality of data and information from this research was kept. Written consent was obtained from each participant.

\section{Competing interests}

The authors affirm that they have no competing interests regarding the publication of this manuscript.

\section{Author details}

${ }^{1}$ Medical Parasitology Department, Faculty of Medicine, Zagazig University, El Kawmia Square, Zagazig 44511, Sharkia Governorate, Egypt. ${ }^{2}$ Clinical Laboratories Department, College of Applied Medical Sciences, Jouf University, Al-Jouf 77451, Saudi Arabia. ${ }^{3}$ Tropical Medicine Department, Faculty of Medicine, Zagazig University, Zagazig 44511, Egypt. ${ }^{4}$ Community, Environmental and Occupational Medicine Department, Faculty of Medicine, Zagazig University, Zagazig 44511, Egypt. ${ }^{5}$ Microbiology Department, Faculty of Medicine, Zagazig University, Zagazig 44511, Egypt. ${ }^{6}$ Internal Medicine Department, College of Medicine, King Faisal University, 31982, Al-Ahsa, Saudi Arabia. ${ }^{7}$ Haematology and Transfusion Medicine, King Abdulaziz University, Jeddah 21577, Saudi Arabia.

Received: 7 December 2020 Accepted: 29 April 2021

Published online: 04 May 2021

\section{References}

1. Luengo-Alonso G, Pérez-Tabernero FG, Tovar-Bazaga M, ArguelloCuenca JM, Calvo E. Critical adjustments in a department of orthopaedics through the COVID-19 pandemic. Int Orthop. 2020;44:1557-64. 
2. Khosrawipour V, Lau H, Kocbach P, Ichii H, Bania J, Mikolajczyk A. Failure in initial stage containment of global COVID-19 epicenters. J Med Virol. 2020:92:863-7.

3. https://covid19. who.int/?gclid=EAlalQobChMI7dTvgr6b7QIVVIBQBh OL5wmZEAAYASAAEgJlh_D BwE. Accessed 24 Nov 2020.

4. Lokken KL, Stull-Lane AR, Poels K, Tsolis RM. Malaria parasite-mediated alteration of macrophage function and increased iron availability predispose to disseminated nontyphoidal Salmonella infection. Infect Immun. 2018:86:301-18.

5. Teo TH, Lum FM, Ghaffar K, Chan YH, Amrun SN, Tan JJL, et al. Plasmodium co-infection protects against Chikungunya virus induced pathologies. Nat Commun. 2018:9:3905.

6. Weeratunga P, Herath TUB, Kim TH, Lee HC, Kim JH, Lee BH, et al. Dense Granule Protein-7 (GRA-7) of Toxoplasma gondii inhibits viral replication in vitro and in vivo. J Microbiol. 2017;55:909-17.

7. Shen SS, Qu XY, Zhang WZ, Li J, Lv ZY. Infection against infection parasite antagonism against parasites, viruses and bacteria. Infect Dis Pover. 2019:8:49.

8. Bilenko N, Levy A, Dagan R, Deckelbaum RJ, El-On Y, Fraser D. Does co-infection with Giardia lamblia modulate the clinical characteristics of enteric infections in young children? Eur J Epidemiol. 2004;19:877-83.

9. https://www.cdc.gov/coronavirus/2019-ncov/symptoms-testing/sympt oms.html. Accessed May 2019.

10. Chen G, Wu D, Guo W, Cao Y, Huang D, Wang H, et al. Clinical and immunological features of severe and moderate coronavirus disease 2019. J Clin Invest. 2020;130:2620-9.

11. Huang C, Wang Y, Li X, Ren L, Zhao J, Hu Y, et al. Clinical features of patients infected with 2019 novel coronavirus in Wuhan China. Lancet. 2020;395:497-506.

12. Lee AJ, Ashkar AA. The dual nature of type I and type II interferons. Front Immunol. 2018:9:2061.

13. Sommereyns C, Paul S, Staeheli P, Michiels T. IFN-lambda (IFN-lambda) is expressed in a tissue-dependent fashion and primarily acts on epithelial cells in vivo. PLOSPathog. 2008;4:e1000017.

14. Hu ZJ, Xu J, Yin JM, Li L, Hou W, Zhang LL, et al. Lower circulating interferon-gamma is a risk factor for lung fibrosis in COVID-19 patients. Front Immunol. 2020. https://doi.org/10.3389/fimmu.2020.585647.

15. Degrandi D, Hoffmann R, Beuter-Gunia CK, Pfeffer K. Teproinfammatory cytokine-induced IRG 1 protein associates with mitochondria. J Interferon Cytokine Res. 2009;29:55-67.

16. Daniels BP, Kofman SB, Smith JR, Norris GT, Snyder AG, Kolb JP, et al. Te nucleotide sensor ZBP1 and kinase RIPK3 induce the enzyme IRG1 to promote an antiviral metabolic state in neurons. Immunity. 2019;50:64-76.e4.

17. Can H, ErkuntAlak SE, Köseoğlu AE, Döşkaya M, Ün C. Do Toxoplasma gondii apicoplast proteins have antigenic potential? An in silico study. Comput Biol Chem. 2020;84:107158
18. Bartelt LA, Bolick DT, Kolling GL, Roche JK, Zaenker El, Lara AM, et al. Cryptosporidium priming is more effective than vaccine for protection against Cryptosporidiosis in a murine protein malnutrition model. PLOS Negl Trop Dis. 2016;10:e0004820. https://doi.org/10.1371/journal.pntd. 0004820.

19. McFarlane AJ, McSorley HJ, Davidson DJ, Fitch PM, Errington C, Mackenzie $\mathrm{KJ}$, et al. Enteric helminth-induced type I interferon signaling protects against pulmonary virus infection through interaction with the microbiota. J Allergy Clin Immunol. 2017;140:1068-78.e6.

20. Bajwa A, Huang L, Kurmaeva E, Ye H, Dondeti KR, Chroscicki P, et al. Sphingosine kinase 2 deficiency attenuates kidney fibrosis via IFN-gamma. J Am Soc Nephrol. 2017:28:1145-61.

21. Levy DE, García-Sastre A. The virus battles: IFN induction of the antiviral state and mechanisms of viral evasion. Cytokine Growth Factor Rev. 2001;12:143-56.

22. Li G, De Clercq E. Therapeutic options for the 2019 novel coronavirus (2019-nCoV). Nat Rev Drug Discov. 2020;19:149-50.

23. Cohen SB, Maurer KJ, Egan CE, Oghumu S, Satoskar AR, Denkers EY. CXCR3-dependent CD4T cells are required to activate inflammatory monocytes for defense against intestinal infection. PLOSPathog. 2013;9:e1003706

24. Scharton-Kersten TM, Yap G, Magram J, Sher A. Inducible nitric oxide is essential for host control of persistent but not acute infection with the intracellular pathogen Toxoplasma gondii. J Exp Med. 1997;185:1261-73.

25. Settles EW, Moser LA, Harris TH, Knoll LJ. Toxoplasma gondii upregulatesinterleukin-12 to prevent Plasmodium berghei —induced experimental cerebral malaria. Infect Immun. 2014;82:1343-53.

26. Tessema TS, Schwamb B, Lochner M, Förster I, Jakobi V, Petry F. Dynamics of gut mucosal and systemic Th1/Th2 cytokine responses in interferon-gamma and interleukin-12 p40 knockout mice during primary and challenge Cryptosporidium parvum infection. Immunobiology. 2009;214:454-66

27. Thompson MG, Breiman RF, Hamel MJ, Desai M, Emukule G, Khagayi S, et al. Influenza and malaria coinfection among young children in western Kenya 2009-2011. J Infect Dis. 2012;206:1674-84.

28. Waldman E, Tzipori S, Forsyth JR. Separation of Cryptosporidium species oocysts from feces by using a percoll discontinuous density gradient. J Clin Microbiol. 1986;23:199-200.

29. Henriksen S, Pohlenz J. Staining of cryptosporida by a modified ZiehlNeelsen technique. Acta Vet Scand. 1981:22:594-6.

\section{Publisher's Note}

Springer Nature remains neutral with regard to jurisdictional claims in published maps and institutional affiliations.

Ready to submit your research? Choose BMC and benefit from

- fast, convenient online submission

- thorough peer review by experienced researchers in your field

- rapid publication on acceptance

- support for research data, including large and complex data types

- gold Open Access which fosters wider collaboration and increased citations

- maximum visibility for your research: over $100 \mathrm{M}$ website views per year

At BMC, research is always in progress.

Learn more biomedcentral.com/submissions 